\title{
The Effectiveness of Education to Increase Motivation and Primary Cervical Cancer Prevention Actions
}

\section{Dewa Ayu Ketut Surinati 1*, I Gede Widjanegara ${ }^{2}$, Suratiah ${ }^{3}$, Nym Ribek}

1,2,3,4 Poltekkes Kemenkes Denpasar, Denpasar, Indonesia

A R T I C L E I N F O

Article history:

Received 20 August z2020

Received in revised Form 27 September 2020

Accepted 20 October

2020

Available online 01

November 2020

Keywords:

Education, Motivation,

Prevention, Cervical

Cancer

\begin{abstract}
A B S T R A C T
Cervical cancer is a type of malignancy found among women, with the second highest number of sufferers globally aged 15 to 44 . However, the motivation for women to do cervical cancer prevention is still low. This study aimed to test the effectiveness of education on motivation and primary prevention measures for cervical cancer in young women. The research method used was an experimental design with a pre-test post-test control group design. The sampling technique used was a proportional random sampling of 150 respondents who met the inclusion criteria, 75 as the experimental group, and 75 as the control group. The statistical test used was Wilcoxon and Mann Whitney test. The Wilcoxon test results showed that the $p$ score was 0.000 $<0.05$, which means a significant difference in motivation and action in the experimental and control groups before and after education. Test results. Mann Whitney showed a p score was $0.000<0.05$. Based on these results, it can be concluded that education effectively increases motivation and the primary prevention of cervical cancer.
\end{abstract}

\section{Introduction}

Cervical cancer is a type of malignancy found among women, and the number is also very high. Every year no less than 15,000 cases of cervical cancer occur in Indonesia. Cervical cancer is the number 1 female killer disease in Indonesia (Ahmad, 2017; Information Center on HPV and Cancer, 2017). The number of new cervical cancer cases in 2012 was 528,000, and the number of deaths was 266,000 (IARC, 2012). From 80 million people in United State, one in four people is infected with Human Papilloma Virus (HPV), and 14 million people are newly infected with HPV each year (Avriel syafiyah, 2017; Setiawati, 2014). From 2010 to 2013, cervical cancer is a disease caused by HPV infection with an increasing number of cases and deaths in Indonesia (Kemenkes RI, 2016).

Cervical cancer cases in Bali in 2011 were around 150 per 100,000 population or around 5000 people, and the mortality rate was around 82 people per 100,000 population. In 2013 , the prevalence of cervical cancer in Bali had increased by $0.7 \%$ or 1,438 people. (Indonesian Ministry of Health, 2015). The incidence of uterine cervical cancer reaches 43 people per 100 thousand population or around $0.89 \%$ and 3.9 million residents of Bali and 553 thousand women of childbearing age included in the risk group (Oktaviani B.D., 2018). Cervical cancer cases according to the data from the Denpasar City Health Office, in 2012, there were 1691 people out of 101,999 women (1.66\%). In 2013 there were 1703 people out of 96,260 women (1.77\%) (Denpasar City Health Office, 2013). In the preliminary study, the KIA officer at Puskesmas Kuta Utara said that in 2018, there were 7 cases of cervical cancer aged 30-40 years and one person had died at 27.

Based on the data above, if cervical cancer cases are not prevented immediately, this disease can cause morbidity, infertility, and an increased mortality rate. It becomes a serious threat to women. Various attempts have been made to prevent cervical cancer, such as counseling programs, the HPV vaccine. However, these efforts have not been satisfactory. It means that for the next few decades, you will still be dealing with cervical cancer.

The high number of deaths due to cervical cancer in Indonesia and exacerbated by patients' arrival to health services at an advanced stage of $>$ 70\% (Siswati, 2012; Susantiningsih et al., 2020). Early 
detection programs will be able to reduce the mortality rate from cervical cancer. However, a few Indonesian women still carry out early detection, including doing cervical cancer prevention properly (Siswati, 2012). Prevention of cervical cancer can be done by primary, secondary, and tertiary prevention. Primary prevention of cervical cancer is carried out by educating a healthy lifestyle, including delaying sexual activity, using barrier contraception, and using the HPV vaccine (Asempah, 2020; Rasyidi, 2009). Several primary ways are very easy and cheap to prevent infection, leading to cervical cancer including; healthy sexual behavior such as being loyal to a partner, using condoms, and maintaining the genital organs/vaginal hygiene (Krisnandi, 2005 in Siswati), 2012). Primary prevention based on cervical cancer risk factors: avoid smoking, avoid premature sexual intercourse, avoid multiple partners, consume vegetables that contain lots of vitamins A, C, E (Dalimarta 2004 in Ningsih, D.U., Sumariani S, 2011).

Prevention of cervical cancer is best done with primary prevention because primary prevention has not led to cervical cancer symptoms. The advantage of primary prevention is that it is very easy, cheap and practical to do in daily life by women and at an inexpensive cost (Winde 2005 in Ningsih, D.U., Sumariani S, 2011). One of the programs that the government hopes for is health promotion efforts to increase public awareness to prevent cervical cancer in activities and education on healthy lifestyles (Fadhillah \& Indita, 2019; Ministry of Health, 2018; Pratiwi \& Hikmah, 2016).

Health education or education is part of health promotion is a series of planned lessons, based on logical theories and equipping individuals and groups and the community to influence others, get information to make quality health decisions to improve welfare (Mubarok, 2009, Notoatmodjo, 2014). Education is carried out by persuasion, appeals, invitations, providing information that will provide public awareness to make choices in achieving prosperity (Mubarok, 2009). Through education, it is hoped that it can increase motivation and change women's behavior in the primary prevention of cervical cancer. Motivation is an important factor in determining an option for the primary prevention of cervical cancer. Motivation is a drive from within a person that causes that person to carry out certain activities to achieve goals (Uno, B., 2012).

(Ningsih, D.U., Sumariani S, 2011) revealed an increase in motivation after counseling with an average score of 39.1765 before counseling and 51.588 after counseling. However, there is still a lack of motivation for women to prevent cervical cancer. The study (Use R, 2017) states that there is still a lack of motivation for women to take primary cervical cancer prevention, obtained by the lack of motivation research by $24(20.5 \%) 83$ respondents.

Research by Kairun, N., (2018) states that there are still mothers who do not perform 45\% IVA examination, and only $54 \%$ do. There has not been any research on the effectiveness of education on motivation and primary prevention of cervical cancer in young women in Kecamatan Kuta Utara. From the result of the interviews with 7 teenagers/students, they often consume fast food such as noodles, 4 people said they did not have good vaginal hygiene, for example, change their underwear once a day, not smoking, 2 people who have not been vaccinated.

Adolescents are the nation's next-generation, with many (19.64\%) of Indonesia's total population having existence as agents of change, which manifests their position and role in national development. However, it needs to be realized that adolescents have very complex problems and the transitional period experienced by adolescents, one of which is continuing school, looking for work, becoming a community member, and practicing healthy living. The problem that stands out is the problem of sexuality, sexually transmitted diseases. Therefore it is hoped that adolescents will become the next generation of quality, adolescents who can behave healthy. Hence, it is necessary to be given an understanding of reproductive health to remain clean and healthy. One of the efforts to upload youth concerns with the intensification of educational information communication through a series of activities including counseling, leaflets, booklets (Mardiya, 2019).

The background of this research is very important because it will provide broader scientific insights. This study's results can be used to formulating primary cervical cancer prevention programs in adolescent girls. This study aimed to examine the effectiveness of education on motivation and the primary prevention of cervical cancer in adolescent girls.

\section{Methods}

This study uses a quantitative research approach. This type of research is experimental research with pre-test post-test control group design. This study's treatment provided treatment in the form of education in small group discussions in the experimental group and treatment in conventional lectures in the control group. This research was conducted at SMAN in North Kuta District in 2019. The research subjects were tenth grade students who met the inclusion criteria, 15 years of age, students who had never received primary cervical cancer prevention counseling and the exclusion criteria were not willing 
to be respondents, were not present at the time. research. The sampling technique used in this study was a proportion random sampling technique. The number of samples was 150 people.

Data obtained directly from respondents using a questionnaire. Data analysis used univariate analysis to analyze catagoric variables using Frequency distribution and bivariate analysis to analyze the difference test for each group using the Wilcoxon test with $0.05 \%$ confidence level. The bivariate test to analyze the difference test between groups pre and post-test using the Mannwhitney test. This study has received approval from the Komite etik Penelitian Kesehatan Poltekkes Kemenkes Denpasar

\section{Result and Discussion}

The frequency distribution of primary cervical cancer prevention motivation before and after being given education to the experimental group and control group at SMA N in Kecamatan Kuta Utara in 2019 is presented in Table 1.

Table 1. Frequency Distribution of Motivation Variables

\begin{tabular}{ccccc}
\hline \multirow{2}{*}{ Motivation } & \multicolumn{2}{c}{ Experiment } & \multicolumn{2}{c}{ Control } \\
\cline { 2 - 5 } & Before & After & Before & After \\
\hline Good & 9 & 58 & 6 & 37 \\
Enough & 56 & 17 & 43 & 35 \\
Less & 10 & 0 & 26 & 3 \\
\hline
\end{tabular}

Table 1 showed that the respondents' motivation level before the intervention in the experimental group was found in the medium category was $56(74.7 \%)$. In the control group most of the respondents' motivation level was at a moderate level $43(57.3 \%)$, and after being given education in the experimental group was mostly at a high level of motivation 58 (77.3\%), while in the control group was 37 $(49.3 \%)$.

Table 2. Comparison of Descriptive Statistics of Motivation Variables

\begin{tabular}{ccccc}
\hline \multirow{2}{*}{ Variable } & \multicolumn{2}{c}{ Experiment } & \multicolumn{2}{c}{ Control } \\
\cline { 2 - 5 } & Pre & Post & Pre & Post \\
\hline Mean & 48.29 & 74.36 & 44.73 & 59.73 \\
SD & 3.93 & 2.02 & 3.67 & 6.08 \\
Min-Max & $39-60$ & $70-78$ & $35-55$ & $42-69$ \\
Capaian & $63.36 \%$ & $92.90 \%$ & $55.90 \%$ & $74.60 \%$ \\
\hline
\end{tabular}

Based on Table 2, it can be seen that the average motivation score in the experimental group before education was 48.29 and in the control group was 44.73 . The maximum total score if all the answers to the questionnaire are correct was 80 . The achievement score is obtained from the average score. Compared with the questionnaire's total score in the experimental group before education was 60.36, and the control group was 55.9. Meanwhile, after education, the experimental group's motivation before education was 74.36, and in the control group, the experimental group's achievements were 92.9. In the control group, it was 74.6 .

Table 3. Frequency Distribution Table of Primary Preventive Measured Variables

\begin{tabular}{ccccc}
\hline \multirow{2}{*}{ Action } & \multicolumn{2}{c}{ Experiment } & \multicolumn{2}{c}{ Control } \\
\cline { 2 - 5 } & Before & After & Before & After \\
Good & 32 & 70 & 25 & 60 \\
Deficient & 43 & 5 & 50 & 15 \\
\hline
\end{tabular}

Table 3 showed that the primary preventive measures for cervical cancer before the intervention in the experimental group were found in the poor category $43(57.3 \%)$, in the control group the most was $50(66.7 \%)$ and after being given education in the experimental group was 70 good respondents $(93.3 \%)$. In contrast, in the control group the most respondents act was good 60 (80.05). 
Table 4. Comparison of Descriptive Statistics of Motivation Variables

\begin{tabular}{ccccc}
\hline \multirow{2}{*}{ Variable } & \multicolumn{2}{c}{ Experiment } & \multicolumn{2}{c}{ Control } \\
\cline { 2 - 5 } & Pre & Post & Pre & Post \\
\hline Mean & 7.25 & 10.25 & 7.07 & 8.59 \\
SD & 0.96 & 1.02 & 0.86 & 0.95 \\
Min-Max & $5-10$ & $7-11$ & $5-9$ & $7-10$ \\
Capaian & $60.40 \%$ & $85.40 \%$ & $58.90 \%$ & $71.50 \%$ \\
\hline
\end{tabular}

Based on Table 4, it can be seen that the average action score in the experimental group before education was 7.25 and in the control group was 7.07 from the maximum total score if all the answers to the questionnaire are correct is 12 . Achievement score is obtained from the average score compared with the questionnaire's total score in the experimental group before education was 60.4, and the control group was 58.9. Meanwhile, after education, the experimental group's action achievement score was 85.4 and in the control group was 71.5 .

Table 5. Wilcoxon Test Results for Motivation Variables

\begin{tabular}{cccccc}
\hline \multirow{2}{*}{ Variable } & \multicolumn{2}{c}{ Experiment } & \multicolumn{2}{c}{ Control } \\
\cline { 2 - 6 } & Pre & & Post & Pre & Post \\
\hline Mean & 48.29 & & 74.36 & 44.73 & 59.73 \\
Z & & -7.325 & & & -7.529 \\
P (score) & & 0.000 & & 0.000 \\
\hline
\end{tabular}

Table 5 showed that the average score of primary cervical cancer prevention motivation before and after being given education through small group discussions has increased by 26.07, from 48.29 to 74.36. After analyzing the data using the Wilcoxon test $(a=0.05)$ in the experimental group, $p=0.000$ was obtained, then $\mathrm{p} \leq 0.05$, which means a difference in motivation before and after education SGD. Meanwhile, the average score of cervical cancer primary prevention motivation before and after education with lectures in the control group increased but was smaller than the experimental group 14.44 from 44.73 to 59.17 . After analyzing the data using the Wilcoxon test $(a=0.05), p=0.000$, then $p \leq 0.05$, which means a difference in motivation before and after education.

Table 6. Wilcoxon Test Results for Primary Preventive Variables

\begin{tabular}{cccccc}
\hline \multirow{2}{*}{ Variable } & \multicolumn{3}{c}{ Experiment } & \multicolumn{2}{c}{ Control } \\
\cline { 2 - 6 } & Pre & & Post & Pre & Post \\
\hline Mean & 7.25 & & 10.25 & 7.07 & 8.59 \\
Z & & -7.592 & & & -7.529 \\
P (score) & & 0.000 & & 0.000 \\
\hline
\end{tabular}

Table 6 shows that the average score of cervical cancer primary prevention measures before and after education through small group discussions has increased from 7.25 to 10.25. After analyzing the data using the Wilcoxon test $(a=0.05)$ in the experimental group, $p=0.000$ was obtained, then $p \leq 0.05$, which means that there are differences in primary precautions before and after education through SGD. Meanwhile, the average score of cervical cancer primary prevention before and after education with lectures in the control group increased but was smaller than the experimental group, from 7.07 to 8.59. After analyzing the data using the Wilcoxon test $(a=0.05), p=0.000$, then $p \leq 0.05$, which means that there are differences in primary preventive measures against cervical cancer before and after education.

\section{Discussion}

The average score of cervical cancer primary prevention motivation before and after being given education through a small group discussion has increased by 26.07, from 48.29 to 74.36 . After analyzing the data using the Wilcoxon test $(\mathrm{a}=0.05)$ in the experimental group, $\mathrm{p}=0.000$, then $\mathrm{p} \leq 0.05$, there is a difference in motivation before and after education through SGD. Meanwhile, the average score of cervical cancer primary prevention motivation before and after education with lectures in the control group 
increased but was smaller than the experimental group, 14.44 from 44.73 to 59.17. After analyzing the data using the Wilcoxon test $(a=0.05), p=0.000$, then $p \leq 0.05$, which means a difference in motivation before and after education. The knowledge they have will form a belief or motivate someone to take certain actions, preventing cervical cancer. Motivation is an important part of efforts to combat cervical cancer (Elise et al., 2020). Motivation can be interpreted as internal and external encouragement in a person indicated by the desire and interest to carry out activities, drive and need to carry out activities, hopes and ideals, self-respect and respect, good environment, and interesting activities. Several factors affect a person's motivation for health, including education level, age, economy, environment, and trust (Sugiyanto \& Febriana, 2020). The low motivation of women of childbearing age in detecting cervical cancer due to the lack of information by service centers and the public who are not exposed to information about early detection of cervical cancer. The willingness to care about health is lacking. The affordability of facilities is very far away. It is necessary to socialize the importance of cervical cancer prevention and adequate information sources, so that cervical cancer can be prevented optimally because early detection is a more effective screening.

The results of this study were in line with research conducted by (Elise et al., 2020) which stated that there is an effect of health education on the motivation of WUS, it is necessary to improve health services, especially the provision of health education on early detection of cervical cancer using the IVA method. The research conducted by (Sugiyanto \& Febriana, 2020) states that there is a significant difference in interest in IVA examinations before being given health education and after being given health education. Research conducted by (Ahmad, 2017) states that healthy motivation directly affects cervical cancer prevention behavior.

Before and after being given education through a small group discussion, the average score of cervical cancer primary prevention measures has increased from 7.25 to 10.25. After analyzing the data using the Wilcoxon test $(a=0.05)$ in the experimental group, $p=0.000$, then $p \leq 0.05$, there are differences in primary precautions before and after education SGD. Meanwhile, the average score of cervical cancer primary prevention before and after education with lectures in the control group increased but was smaller than the experimental group, from 7.07 to 8.59. After analyzing the data using the Wilcoxon test (a $=0.05), p=0.000$, then $p \leq 0.05$, which means that there were differences in primary preventive measures against cervical cancer before and after education. Education through SGD begins with conveying real problems whose solutions require cooperation among students or group members. The atmosphere can be created flexible and oriented towards problem-solving efforts Izzan (2009). Through small group discussions, education makes students experience a significant increase in knowledge because discussions can increase critical activeness participation, understanding, and completeness in learning. Health education, especially using the small group discussion method, is very important to increase cervical cancer knowledge. According to Sanjaya, W, (2010), with the SGD method, respondents are actively involved in discussion groups to explore problems and solve problems with the group. With the small group discussion method, students of SMA Negeri Kerambitan remember the material and can also understand and develop the ability to analyze situations more responsible in learning.

This study's results are in line with research conducted by (Susantiningsih et al., 2020), which states that counseling activities regarding the dangers of cervical cancer in Al Kautsar Pangkalan Jati recitation mothers RT 007 / RW 007 Cinere Depok can be well received by participants and participants. get additional knowledge about the dangers of cervical cancer, it can be seen by the increase in post-test scores after counseling about the dangers of cervical cancer by $2 \%$, from $84 \%$ to $86 \%$. The research conducted by (Atmi, 2017) states that based on the results of the analysis and research objectives on "Health Information Sharing Behavior among Cervical Cancer Patients, "the researcher concluded that there are different behavioral models of sharing information among cervical cancer patients in Surabaya. patient when diagnosed with cervical cancer. The research conducted by (Herniyatun et al., 2009) stated that cervical cancer prevention attitudes and skills are not influenced by age and level of education but influenced by peer group educational interventions that can change cervical cancer prevention behavior, which can transfer knowledge about prevention completely, so that not only attitudes and skills can change, but all peer group members in Kebume can also own broad knowledge about cervical cancer.

\section{Conclusion}

The results showed better knowledge than before, and there was a difference between the pre and post-test scores. So it can be concluded that the small group discussion education model is effective in increasing adolescent knowledge about HIV AIDS at SMAN in Kerambitan District, Tabanan. 


\section{References}

Ahmad, M. (2017). Persepsi tentang Kanker Serviks, Promosi Kesehatan, Motivasi Sehat terhadap Perilaku Pencegahan Kanker Serviks pada Bidan di Wilayah Depok. Jurnal Ilmiah Kesehatan, 16(2), 3241. https://doi.org/10.33221/jikes.v16i2.11

Asempah, E. (2020). HPV vaccine and cervical cancer policy and policymaking research interest in subSaharan Africa: A scoping review. Journal of Cancer Policy, 26, 100258. https://doi.org/10.1016/j.jcpo.2020.100258

Atmi, R. T. (2017). Model perilaku berbagi informasi kesehatan di kalangan pasien kanker serviks Model. RECORD AND LIBRARY JOURNAL, 3(2), 1689-1699. https://doi.org/https://doi.org/10.20473/rlj.V3-I2.2017.139-157

Avriel syafiyah. (2017). HPV (Human Papilloma Virus) ; Gejala dan pengobatan,. news,gunadarma.

Dinkes Kota Denpasar. (2013). PROFIL KESEHATAN KOTA DENPASAR TAHUN 2013.

Elise, E., Yuliana, Y., \& Wahyuni, W. (2020). Pengaruh Pendidikan Kesehatan Tentang Deteksi Dini Kanker Serviks terhadap Motivasi dalam Melakukan Pemeriksaan Iva di Puskesmas Pal III Pontianak Tahun 2019. Jurnal Kebidanan, 10(1), 326896. http://jurnal.akpbpontianak.ac.id/index.php/123akpb/article/view/94

Fadhillah, I., \& Indita, W. (2019). Peran Petugas Kesehatan Dalam Upaya Pencegahan Kanker Serviks Melalui Peningkatan Cakupan Pemeriksaan Inspeksi Visual Asam Asetat (IVA) di Kelurahan Campurejo Kecamatan Kota Kediri. Jurnal Ners Dan Kebidanan (Journal of Ners and Midwifery), 6(3), 300-309. https://doi.org/10.26699/jnk.v6i3.art.p300-309

Herniyatun, H., Astutiningrum, D., \& Nurlaila, N. (2009). EFEKTIVITAS EDUKASI PEER GROUP TERHADAP PERUBAHAN PENGETAHUAN, SIKAP DAN KETRAMPILAN DALAM PENCEGAHAN KANKER SERVIK DI KABUPATEN KEBUMEN. Jurnal Ilmiah Kesehatan Keperawatan, 5(2), 109-118. http://ejournal.stikesmuhgombong.ac.id/JIKK/article/view/54

IARC. (2012). Globocan 2012 : Cancer Fact Sheet. 2012.

Information Centre on HPV and Cancer. (2017). Human Papillomavirus and Related Diseases Report. May.

Izzan, A. (2009). Metodologi Pembelajaran Bahasa Arab.

Kemenkes. (2016). InfoDatin Bulan Peduli Kanker Payudara 2016.

Kemenkes. (2018). Panduan_Pelaksanaan_Hari_Kanker_Sedunia_2018.pdf.

Kemenkes RI. (2015). Infodatin Kanker Pusat Data dan Informasi Kementerian Kesehatan RI.

Mardiya. (2019). Mengunggah Kepedulian Remaja Terhadap Permasalahan Kependudukan Di Indonesia.

Mubarok. (2009). Ilmu Kesehatan Masyarakat Teori dan aplikasi ,.

Ningsih, D.U., S. S. (2011). Pengaruh Penyuluhan Kesehatan Terhadap Motivasi Dalam Upaya Pencegahan Primer Kanker Serviks Pada Siswi Kelas X Di Sma Negeri 1 Sanden, Bantul, Yogyakarta.

Notoatmodjo. (2014). Ilmu Perilaku Kesehatan.

Oktaviani B.D. (2018). Karakteristik Klinikopatologi Penderita Kanker Serviks Uteri Berdaasarkan Data di Lab PA RSUP Sanglah Tahun 2011-2015. 7(8).

Pakkan, R. (2017). Metode Inspeksi Visual Asam Asetat ( Iva ) Di Kelurahan Lepo-Lepo Kota Kendari. Jurnal Ilmiah Bidan, Vol.Ii, No.1, 2017, Ii(1), 1-6.

Pratiwi, M. L. E., \& Hikmah, H. (2016). Strategi Komunikasi Bahaya Kanker Serviks di Puskesmas Ngampilan Tahun 2015. Komunikator, 8(1).

https://journal.umy.ac.id/index.php/jkm/article/view/1795

Rasyidi. (2009). Deteksi dini pencegahan kanker pada wanita.

Setiawati, D. (2014). Human Papilloma Virus Dan Kanker Serviks. Public Health Science Journal, Vol. VI, N, 
$450-459$.

Siswati. (2012). Pengaruh pendidikan kesehatan terhadap peningkatan motivasi mencegah kanker servik pada ibu jalasenastri di pangkalan tni angkatan laut cilacap.

Sugiyanto, S., \& Febriana, T. N. (2020). Pengaruh pendidikan kesehatan tentang kanker serviks terhadap minat pemeriksaan IVA pada kelompok ibu pengajian. Jurnal Kebidanan Dan Keperawatan Aisyiyah, 12(2), 158-162. https://doi.org/10.31101/jkk.307

Susantiningsih, T., Makkiyah, F. A., \& Setyaningsih, Y. (2020). Pelatihan dan Penyuluhan mengenai Bahaya Kanker Serviks pada Kelompok Ibu-ibu Pengajian di Pangkalan Jati, Cinere, Depok. Jurnal Pengabdian Pada Masyarakat, 5(2), 554-563.

https://doi.org/https://doi.org/10.30653/002.202052.319

W, S. (2010). Strategi Pembelajaran: Berorentasi Standar Proses Pendidikan. 